\title{
A Review on Waste Minimization by Adopting in Self Compacting Concrete
}

\author{
S. Shahidan ${ }^{1, a}$, I. Isham ${ }^{1}$ and N. Jamaluddin ${ }^{1}$ \\ ${ }^{1}$ Faculty of Civil and Environmental Engineering, Universiti Tun Hussein Onn Malaysia, 86400 Parit Raja, Johor, \\ Malaysia
}

\begin{abstract}
Self-compacting concrete (SCC) was first developed in late 80's in Japan. SCC is well known for its self-consolidation and able to occupy spaces in the formwork without vibration and become new interesting topic in Construction and Building Materials Research. The aim of this review is to summaries the previous research work related to utilization of waste minimization in SCC from 2009 to 2015 through available literature. It is important to expose new researchers on concept and fundamental theory developed by previous researchers as a reference and guidance in their research. There were a lot of opportunity to be explored in developing SCC especially in utilizing waste material as replacement materials or additives used and mix design method for rheological improvement in SCC. However, these review only focusing on waste materials that have significant to be taken care to reduce environmental impact such as waste product from construction industry and by product industry. As conclusion, this paper will provide significant idea and useful information to those new to SCC and fellow researchers for future studies in utilizing waste materials in SCC mix design.
\end{abstract}

\section{Introduction}

Developing Self Compacting Concrete (SCC) was started in late ' $80 \mathrm{~s}$ in Japan. It was introduce by Okamura Hajime [1-2] due to shortage of manpower on site and resolve environmental issue such as noise reduction. This concrete technology has received demand from construction industry in Japan to construct bridges, buildings and repair works on site.

In definition, SCC is the technology of concrete that makes use of concrete to flow and fill the gap between reinforcement and fill the void inside the formwork at every corner by it is own weight without vibration process [3-4]. The development of SCC for construction industry in Japan has proved benefit in several factors such as reduce construction duration, required less manpower on site, provide good surface finishes, easier in placing handling, provided freedom idea in structural design, suitable for thinner concrete sections, reduced noise levels and safer working environment $[3,5]$.

However, the development of SCC still under continues research. This was confirmed by the summary of literature review from published journal since 2009 to 2015 as shown in Table 1. Some of researcher's study on utilizing additive materials, chemical additive, waste materials, light weight aggregate, sand replacement and potential pozzolana materials to improve rheological and hardened properties. However, these summaries only focus on waste materials used in previous research from

\footnotetext{
${ }^{\text {a }}$ Corresponding author : shahiron@uthm.edu.my
} 
Turkey, Greece, India, Thailand, Malaysia, Iran, China, Indonesia, Brazil, Taiwan, Italy, Tunisia and Germany. Hopefully this information can provide an idea for new researcher to explore on SCC by utilizing waste materials that available from construction industry and also from by product industry. The performance of waste materials in SCC is based on fresh state [3, 6-10] and hardened state.

\section{Literature from Previous Researches}

This review based on information gathered from available literature journal papers since 2009 till 2015. Table 1(a) and (b) have shown the previous research focusing on waste materials in development of sustainable SCC for benefit of economy and environmental issues. It was clearly shown that utilizing waste materials in SCC have significant contribution to environmental solution and indirectly help to contribute in generating economic value to some other industries.

Table 1(a). Summary of previous study base on waste materials used in SCC.

\begin{tabular}{|c|c|c|c|c|}
\hline Year & Ref. & Country & Materials & Finding \\
\hline \multirow{2}{*}{2009} & {$[11]$} & Turkey & $\begin{array}{l}\text { Mix design using marble powder } \\
\text { (MP) (recycle value) }\end{array}$ & $\begin{array}{c}\text { Mix design Monogram. Recycle powder successfully and } \\
\text { economically as filler material, } \mathrm{f}_{\mathrm{c}}( \pm) \text { 20-60 MPa, using } \\
\text { Mix design base on Monogram }\end{array}$ \\
\hline & [12] & USA & $\begin{array}{l}\text { Mix design using foundry silica } \\
\text { dust (SD) as replacement for FA } \\
\text { (economic value) }\end{array}$ & $\begin{array}{l}20 \% \text { SD as economy cost, } 30 \% \text { SD increase demand of } \\
\text { HRWA (increase cost of material } 14 \%), \mathrm{f}_{\mathrm{c}}( \pm) 34-62 \mathrm{MPa}\end{array}$ \\
\hline \multirow{2}{*}{2010} & [13] & Greece & $\begin{array}{l}\text { Mix design cement paste, SF, Nano } \\
\text { SF, LS, P \& FA for viscosity effect }\end{array}$ & $\begin{array}{c}\text { Cement paste, } 40 \% \text { LS improved rheological behavior, } \\
20 \% \text { LS \& } 20 \% \text { FA having higher packing density. SF \& } \\
\text { Pozzolan having lower viscosity }\end{array}$ \\
\hline & [14] & India & $\begin{array}{l}\text { Mix design cement replacement } \\
\text { using SF Vs LS, QD \& Cl } \\
\text { (comparison water absorption) }\end{array}$ & $\begin{array}{l}\text { Okamura's Method. SF increased dosage SP, improved } \\
\text { aggregate matrix bonding \& less water absorption (better } \\
\text { than QD \& LP), LP improved \& better workability }\end{array}$ \\
\hline \multirow{3}{*}{2011} & {$[15]$} & UK & $\begin{array}{l}\text { Mix design (Dolomite Powder }+ \\
\text { FA) Vs (LS + FA). Utilizing DP as } \\
\text { alternative materials }\end{array}$ & $\begin{array}{c}\text { Mix by Mass. Utilizing DP with FA can reduced cost } \\
\text { SCC \& solution to disposal \& environmental problem. } \\
\text { But, increase DP and decrease FA will reduce } \\
\text { compressive strength. }\end{array}$ \\
\hline & [16] & Italy & $\begin{array}{l}\text { Mix design mineral addition. FA, } \\
\text { LP, (Rubble Powder + Fine } \\
\text { Recycle) \& (RP + Course Recycled })\end{array}$ & $\begin{array}{l}\text { MP performed better in rheological test. All mix obtained } \\
\text { satisfactory in compressive strength }( \pm) 40 \mathrm{MPa} \text {. }\end{array}$ \\
\hline & [17] & Turkey & $\begin{array}{l}\text { Mix design mineral admixtures. FA, } \\
\text { GBFS, LP, BP and MP for cement } \\
\text { replacement }\end{array}$ & $\begin{array}{c}\text { FA \& GBFS increased compressive strength \& } \\
\text { workability, replacement FA in OPC suitable for HPC }\end{array}$ \\
\hline \multirow[t]{2}{*}{2012} & [18] & Algeria & $\begin{array}{l}\text { Mix design using various sand } \\
\text { (Crushed Sand, River Sand, Dund } \\
\text { Sand \& mix sand) }\end{array}$ & $\begin{array}{l}\text { Okamura's Method. Increase fine LS, decrease slump } \\
\text { flow time \& increased V Funnel flow time, } 10-15 \% \text { fine } \\
\text { LS improved rheological and compressive strength of } \\
\text { mortar but more than that will decreased it strength. DS } \\
\text { required higher water demand and larger amount of } \\
\text { cement compared with RS \& CS }\end{array}$ \\
\hline & [19] & Turkey & $\begin{array}{l}\text { Mix design MP, LS \& FA as filler } \\
\text { (Environmental Concern; disposal } \\
\text { \& recycled materials) }\end{array}$ & $\begin{array}{l}\text { Integration of MP \& LS with FA improved workability, } \\
\text { MP \& LS increase dosage of SP but integration with FA } \\
\text { decreased amount of SP. }\end{array}$ \\
\hline \multirow{5}{*}{2013} & [20] & Brazil & $\begin{array}{l}\text { Mix design using kaolin waste as } \\
\text { agg. replacement }\end{array}$ & $\begin{array}{c}\text { Mix using concept of aggregate skeleton (increase } \\
\text { compactness will increase density), only focus on fresh } \\
\text { test }\end{array}$ \\
\hline & [21] & Taiwan & $\begin{array}{l}\text { Mix design FA \& slag with } \\
\text { difference w/c ratio }\end{array}$ & $\begin{array}{c}\text { Densified mixture design algorithm (DMDA), DMDA } \\
\text { minimize paste content \& overcome aggregate gradation, } \\
\text { provide high slump without bleeding \& segregation, used } \\
\text { less cementitious materials ratio will effect early strength } \\
\text { but not for long term strength (after } 56 \text { days) }\end{array}$ \\
\hline & [22] & Indonesia & $\begin{array}{l}\text { Mix design using roof tile powder } \\
\text { (RTP) }\end{array}$ & $\begin{array}{l}20 \% \text { RTP, compressive strength } 67.72 \mathrm{MPa} \text {, good flow } \\
\text { ability }\end{array}$ \\
\hline & [23] & UK & $\begin{array}{l}\text { Mix design using FA \& LP as a } \\
\text { filler }\end{array}$ & $\begin{array}{l}30 \% \text { FA for sustainable SCC with approximately } 1.83 \% \\
\text { SP (by weight), compressive strength } 50-60 \mathrm{MPa},\end{array}$ \\
\hline & [24] & India & $\begin{array}{l}\text { Mix design using recycled } \\
\text { aggregate }\end{array}$ & $\begin{array}{l}10-40 \% \text { RA, increase RA will decrease compressive, } \\
\text { flexural \& tensile strength }\end{array}$ \\
\hline
\end{tabular}


Table 1(b). Summary of previous study base on waste materials used in SCC.

\begin{tabular}{|c|c|c|c|c|}
\hline Year & Ref. & Country & Materials & Finding \\
\hline \multirow{3}{*}{2013} & {$[25]$} & Thailand & $\begin{array}{l}\text { Mix design using untreated RHA \& } \\
\text { PFA }\end{array}$ & $\begin{array}{l}\text { Compressive strength of } 40 \% \text { RHA decreased } 1 / 3 \text { from } \\
\text { control sample }\end{array}$ \\
\hline & [26] & Thailand & $\begin{array}{l}\text { Mix design using cathode ray tube } \\
\text { waste }\end{array}$ & Increase CRT amount will decrease compressive strength \\
\hline & {$[27]$} & Thailand & $\begin{array}{c}\text { Mix design using recycled alumina } \\
\text { waste (AW) as fine aggregate } \\
\text { replacement }\end{array}$ & $\begin{array}{c}\text { AW increased amount of SP, AW increased compressive } \\
\text { strength over the period, } 75 \% \text { AW have better } \\
\text { compressive strength than control sample }\end{array}$ \\
\hline \multirow{10}{*}{2014} & {$[28]$} & Greece & $\begin{array}{l}\text { Mix design using ladle furnace slag } \\
\text { (LFS) and steel fiber reinforcement }\end{array}$ & $\begin{array}{l}\text { LFS as filler improved compressive strength \& durability } \\
\text { (freezethraw resistance \& chloride penetration) with } \\
\text { consistence workability, LFS with fibre increase fracture } \\
\text { toughness but to many fibre will effect segregation and } \\
\text { flowability, increase LFS decrease water cement ratio }\end{array}$ \\
\hline & {$[29]$} & Turkey & $\begin{array}{c}\text { Mix design using Low Lime Fly } \\
\text { Ash (LLFA) \& GBFS as cement } \\
\text { replacement (binder) \& Mircronized } \\
\text { Calcite (MC) as aggregate } \\
\text { replacement }\end{array}$ & $\begin{array}{l}\text { LLFA, GBFS \& MC positively improved passing ability } \\
\text { \& flow ability \& reduce viscosity (due to MC), surface } \\
\text { roughness LLFA reduce water demand, substitution high } \\
\text { volume of GBFS \& LLFA up to } 60 \% \text { (compressive } \\
\text { strength } 42.58-52.7 \mathrm{MPa} \text { ) }\end{array}$ \\
\hline & {$[30]$} & Iran & Mix design effect of aggregate sizes & Decrease of aggregate size will drop fracture energy \\
\hline & {$[31]$} & Turkey & $\begin{array}{l}\text { Mix design utilizing of VMA to } \\
\text { reduce fine material }\end{array}$ & $\begin{array}{l}\text { Increase fine material or use VMA to avoid segregation, } \\
\text { VA xanthan gum @ } 400 \mathrm{~kg} \text { binder content \& VA starch } \\
\text { ether (@350,400\&450 kg binder dosage) reduce } \\
\text { bleeding to zero, at some portion segregation will effect } \\
\text { compressive strength, W/C ratio significantly effect the } \\
\text { compressive strength same as NVC }\end{array}$ \\
\hline & {$[32]$} & Malaysia & $\begin{array}{l}\text { Mix design using Palm Oil Clinker } \\
\text { (POC) as LWA }\end{array}$ & $\begin{array}{l}\text { Mix design base on particle packing (PP) can be used to } \\
\text { predict hardened properties, }\end{array}$ \\
\hline & {$[33]$} & UK & $\begin{array}{l}\text { Mix design using Recycled Lime } \\
\text { Powder (RLP) \& Recycled } \\
\text { Concrete Aggregate (RCA) } \\
\end{array}$ & $\begin{array}{l}\text { RLP as cement replacement \& RCA as aggregate } \\
\text { replacement have potential to produce good quality } \\
\text { (mechanical \& durability performance) }\end{array}$ \\
\hline & {$[34]$} & Malaysia & $\begin{array}{c}\text { Mix design using Metakaolin (MK) } \\
\text { with difference course aggregate } \\
\text { properties }\end{array}$ & $\begin{array}{l}10 \% \mathrm{MK} \text { as pozzolan by weight of cement good in } \\
\text { workability and strength, same w/b ratio \& SP dosage but } \\
\text { increase sand content (mortar) will reduce flow ability } \\
\text { (lead to bleeding rate of water), SP increase with } \\
\text { increasing of MK, higher SP dosage contribute to } \\
\text { bleeding, shape \& fineness powder effect SP dosage, }\end{array}$ \\
\hline & {$[35]$} & Malaysia & $\begin{array}{l}\text { Mix design using RHA and blended } \\
\text { fine aggregate }\end{array}$ & $\begin{array}{l}\text { RHA as supplementary of cement, suitable for normal } \\
\text { strength, compressive strength \& splitting tensile strength } \\
\text { decreased with increasing of RHA, RHA contain silica } \\
\text { which not contribute to compressive strength }\end{array}$ \\
\hline & {$[36]$} & Turkey & $\begin{array}{l}\text { Mix design using waste marble } \\
\text { (WM) and recycled aggregates } \\
\text { (RA) }\end{array}$ & $\begin{array}{l}\text { Crushed limestone agg. as control sample, WM \& RA } \\
\text { produce slightly lower compressive strength compared } \\
\text { with CLS, strength can be improved by reduce w/b ratio }\end{array}$ \\
\hline & {$[37]$} & Malaysia & Mix design using Bottom Ash & $\begin{array}{l}10-15 \% \text { BA suitable for fine aggregate replacement, more } \\
\text { than that it will effect the rheology properties }\end{array}$ \\
\hline \multirow{6}{*}{2015} & {$[38]$} & India & Mix design using RHA & $\begin{array}{c}\text { RHA as supplementary cementitious material, } 15 \% \text { RHA } \\
\text { increased compressive strength \& tensile strength and also } \\
\text { reduced chloride ion penetration }\end{array}$ \\
\hline & {$[39]$} & China & Mix design using FA \& GGBFS & $\begin{array}{c}\text { Combination FA \& GBFS (20,30 \& 40\%) not affect } \\
\text { flowability \& stability, effective on chloride ion } \\
\text { migration, but higher carbonation depth }\end{array}$ \\
\hline & {$[40]$} & China & $\begin{array}{l}\text { Mix design using recycled plastic } \\
\text { particles }\end{array}$ & $\begin{array}{c}\text { For light weight SCC, Compressive strength, tensile } \\
\text { strength \& flexural tensile strength increased with } \\
\text { replacement level up to } 15 \% \text {, }\end{array}$ \\
\hline & {$[41]$} & Germany & $\begin{array}{l}\text { Mix design containing various } \\
\text { mineral admixtures for high } \\
\text { performent concrete (HPC) }\end{array}$ & $\begin{array}{l}\text { Introduced new mix design method containing various } \\
\text { mineral admixtures by using Absolute Volume Method } \\
\text { (AVM) - adopted from packing theory, RHA improved } \\
\text { compressive strength (marginally lower from SF) }\end{array}$ \\
\hline & {$[42]$} & Tunisia & $\begin{array}{l}\text { Mix design using marble and tile } \\
\text { waste as filler }\end{array}$ & $\begin{array}{l}\text { Mix design using "Concrete LabPro2" software, } \\
\text { compressive strength \& tensile strength are sufficient }\end{array}$ \\
\hline & {$[43]$} & Algeria & $\begin{array}{l}\text { Mix design using seashell as fine } \\
\text { aggregate for mortar }\end{array}$ & $\begin{array}{l}\text { For fine aggregate by sand substitution for mortar, } 100 \% \\
\text { replacement reduce compressive strength \& MOE }\end{array}$ \\
\hline
\end{tabular}




\section{Mix design methods}

SCC has been introduced in Japan since 1986 by Okamura using Empirical Design Method [2, 44]. Through summary review from Table 1, it was shown that development of mix design method has been improvised from time to time by researchers around the world. In 2015, Caijun have summarized a review on mix design method for SCC. Base on his reviewed, mix design method can be classified in five categories which are Empirical Design Method, Compressive Strength Method, Close Aggregate Packing Method, Statistical Factorial Method and Rheology of Paste Model. However, all this method still cannot fully meet requirement for effective cost, sustainability, widely applicable due to variable of alternative raw material used and technical requirement while in fresh and hardened state of SCC [44].

From Table 1, it was confirmed that researchers keep on looking on developing mix design method for SCC. For example, it was found that, 3 new methods have been identified such as Monogram Method [11], Absolute Volume Method [41] and "Concrete LabPro2" software [42]. However, those 3 researchers are using difference types of material in their mix design. They have used MP as filler material [11], RHA, SF, FA, LS powder as mineral admixtures for cementations efficiency [41] and marble and tile waste as filler material[42]. Therefore, the ability of each materials to performance with difference mix design method should be open to evaluate as far as the performance in fresh state are well check with the recommendation by [3, 6-10].

\section{Materials}

From Table 1, the most common addition materials are FA, SF, GBFS and LS [3, 45]. While currently researchers have looking forward to make used of recycled material such as Quarry Dust (QD), Dolomite Powder (DP), Limestone (LS), Rubble Powder (RP), Recycled Aggregate, Marble Powder (MP), Cement Klin Dust (CKD), Roof Tiles, Rise Husk Ash (RHA), Alumina Waste (AW), Recycled Plastic Particles (RPP), Marble Waste (MW), Tile Waste (TW), Metakaolin (MK), Basalt Powder (BP) and Palm Oil Clinker (POC). All these additions are used as replacement material or substitution materials either for cement, fine aggregate or filler materials.

Some of this material influence SCC performance in positive effect and some of the materials reflect on negative result either for fresh state or hardened state. Majority of researcher having consistent result in their studies such as FA suitable for cement replacement and fine materials will effect amount of SP required, w/b ratio and w/c ratio. However, uncontrolled amount or proportion of replacement material will reduce the compressive strength, tensile strength, MOE and rheology of the SCC. Therefore the performance of fresh state are compulsory to be checked according to the recommendation by [3, 6-10].

Based on Table 1, it shown that utilizing waste material in SCC have getting attention among researchers. Some of potential waste materials either from construction industry or from by product industry and there are commonly available in every country in all over the world. Those waste materials are abundant and causes environmental pollution such as roof tile [22], recycle aggregate $[24,33,36]$, waste marble [11, 17, 36, 42], RHA [25, 35, 38, 41] and recycled plastic particle [40]. The performances of utilizing those materials are subjective to the purposed of the study and should be explored and established from time to time for the benefit of all parties. A mechanism to utilize all those potential recycled waste materials should be integrated between all parties either from industry or local authorities. This is important to create a better future to our young generation in order to live in sustainable environment.

As conclusion, no doubt, SCC is a potential concrete technology to be developed by utilizing potential alternative materials or waste materials in all over the world. Utilizing of recycled materials and by product materials should be looking forward as an advantage for new researchers especially in Malaysia. It is not only generate or contribute to new knowledge but it is also helping us to save our environment from destructing due to current generated industrial waste in all over the world. 


\section{Conclusions}

From this summary review, it was found that the development of SCC could be explored by using difference types of waste materials especially using by product waste from industry to reduce environmental issues. Indirectly, this effort will provide better solution in concrete technology and create better benefit in future economic value to the industries and local community. Sustainable values on developing future concrete industry should be expended through quality research among industry and collaborate with higher institutions to create sustainable situation to all parties. Beside that, integration with local authorities laws and regulations will generate better opportunity to industries and researchers to collaborate on waste minimization and utilization. Therefore utilizing of waste materials in developing sustainable SCC should be supported, explored and expended through focus researches. Development of SCC should be verified through performance on fresh state and hardened state to understand the behaviour of each material either in short term or long term effect.

\section{Acknowledgement}

This work was supported by Higher Education Ministry Malaysia and Universiti Tun Hussien Onn Malaysia

\section{References}

[1] K.O.H. Okamura and K. Maekawa, High Performance Concrete, Gihoubou Pub. (in Japanese), (1993).

[2] H. Okamura, Self-compacting high-performance concrete, Concr. Int., 50-54, (1997).

[3] EFNARC, Specification and Guidelines for Self-Compacting Concrete, United Kingdom, (2002).

[4] H. Okamura and M. Ouchi, Self-Compacting Concrete, Adv. Concr. Technol., 1(1),. 5-15, (2003).

[5] W. Zhu and P.J.M. Bartos, Permeation properties of self-compacting concrete Wenzhong, Cem. Concr. Res., 21(7), 921-925, (2003).

[6] BS EN12350-Part 8, Testing Fresh Concrete, Self-Compacting Concrete, Slump Flow Test, (2010).

[7] BS EN12350-Part 9, Testing Fresh Concrete, Self-Compacting Concrete, V Funnel Test, (2010)

[8] BS EN12350- Part10, Testing Fresh Concrete, Self-Compacting Concrete, L Box Test, (2010).

[9] BS EN12350-Part 11, Testing Fresh Concrete, Self-Compacting Concrete, Sieve Segregation Test, (2010).

[10]BS EN12350-Part12, Testing Fresh Concrete, Self-Compacting Concrete, J Ring Test, (2010).

[11] K.E. Alyamaç and R. Ince, A preliminary concrete mix design for SCC with marble powders, Constr. Build. Mater., 23(3), 1201-1210, (2009).

[12] R.N. Kraus, T.R. Naik, B.W. Ramme and R. Kumar, Use of foundry silica-dust in manufacturing economical self-consolidating concrete, Constr. Build. Mater., 23(11), 3439-3442, (2009).

[13] N. Diamantonis, I. Marinos, M.S. Katsiotis, A. Sakellariou, A. Papathanasiou, V. Kaloidas and M. Katsioti, Investigations about the influence of fine additives on the viscosity of cement paste for self-compacting concrete, Constr. Build. Mater., 24(8), 1518-1522, (2010).

[14]C. Selvamony, M.S. Ravikumar, S.U. Kannan and S.B. Gnanappa, Investigations on SelfCompacted Self-Curing Concrete Using Limestone Powder and Clinkers, ARPN J. Eng. Appl. Sci., 5(3), 1-6, (2010).

[15] S. Barbhuiya, Effects of fly ash and dolomite powder on the properties of self-compacting concrete, Constr. Build. Mater., 25(8), 3301-3305, (2011).

[16] V. Corinaldesi and G. Moriconi, The role of industrial by-products in self-compacting concrete, Constr. Build. Mater., 25(8), 3181-3186, (2011).

[17] M. Uysal and M. Sumer, Performance of self-compacting concrete containing different mineral admixtures, Constr. Build. Mater., 25(11), 4112-4120, (2011). 
[18]B. Benabed, E.H. Kadri, L. Azzouz and S. Kenai, Properties of self-compacting mortar made with various types of sand, Cem. Concr. Compos., 34(10), 1167-1173, (2012).

[19] M. Gesoğlu, E. Güneyisi, M.E. Kocabağ, V. Bayram and K. Mermerdaş, Fresh and hardened characteristics of self compacting concretes made with combined use of marble powder, limestone filler, and fly ash, Constr. Build. Mater., 37, 160-170, (2012).

[20] G. Azeredo and M. Diniz, Self-compacting concrete obtained by the use of kaolin wastes, Constr. Build. Mater., 38, 515-523, (2013).

[21] Y.Y. Chen, B.L.A. Tuan and C.L. Hwang, Effect of paste amount on the properties of selfconsolidating concrete containing fly ash and slag, Constr. Build. Mater., 47, 340-346, (2013).

[22]B. Herbudiman and A.M. Saptaji, Self-compacting concrete with recycled traditional roof tile powder, Procedia Eng., 54, 805-816, (2013).

[23] M.K. Mohammed, A.R. Dawson and N.H. Thom, Production, microstructure and hydration of sustainable self-compacting concrete with different types of filler, Constr. Build. Mater., 49, 8492, (2013).

[24] K.C. Panda and P.K. Bal, Properties of self compacting concrete using recycled coarse aggregate, Procedia Eng., 51, 159-164, (2013).

[25] G. Sua-iam and N. Makul, Use of Unprocessed Rice Husk Ash and Pulverized Fuel Ash in the Production of Self-compacting Concrete, IERI Procedia, 5, 298-303, (2013).

[26] G. Sua-iam and N. Makul, Use of limestone powder during incorporation of Pb-containing cathode ray tube waste in self-compacting concrete, J. Environ. Manage., 128, 931-940, (2013).

[27] G. Sua-Iam and N. Makul, Use of recycled alumina as fine aggregate replacement in selfcompacting concrete, Constr. Build. Mater., 47, 701-710, (2013).

[28]E.K. Anastasiou, I. Papayianni and M. Papachristoforou, Behavior of self compacting concrete containing ladle furnace slag and steel fiber reinforcement, Mater. Des., 59, 454-460, (2014).

[29]H.Y. Aruntas, Workability and mechanical properties of self-compacting concretes containing LLFA, GBFS and MC, 73, 626-635, (2014).

[30] M.H.A. Beygi, M.T. Kazemi, I.M. Nikbin, J. Vaseghi Amiri, S. Rabbanifar and E. Rahmani, The influence of coarse aggregate size and volume on the fracture behavior and brittleness of selfcompacting concrete, Cem. Concr. Res., 66, 75-90, (2014).

[31]I.E. Isik and M.H. Ozkul, Utilization of polysaccharides as viscosity modifying agent in selfcompacting concrete, Constr. Build. Mater., 72, 239-247, (2014).

[32] J. Kanadasan and H.A. Razak, Mix design for self-compacting palm oil clinker concrete based on particle packing, Mater. Des., 56, 9-19, (2014).

[33]A. Kanellopoulos, D. Nicolaides and M.F. Petrou, Mechanical and durability properties of concretes containing recycled lime powder and recycled aggregates, Constr. Build. Mater., 53, 253-259, (2014).

[34] O.R. Khaleel and H. Abdul Razak, Mix design method for self compacting metakaolin concrete with different properties of coarse aggregate, Mater. Des., 53, 691-700, (2014).

[35] M.E. Rahman, A.S. Muntohar, V. Pakrashi, B.H. Nagaratnam and D. Sujan, Self compacting concrete from uncontrolled burning of rice husk and blended fine aggregate, Mater. Des., 55, 410-415, (2014).

[36] T. Uygunoğlu, I.B. Topçu and A.G. Çelik, Use of waste marble and recycled aggregates in selfcompacting concrete for environmental sustainability, J. Clean. Prod., 84, (2014).

[37] N.E. Zainal Abidin, M.H. Wan Ibrahim, N. Jamaluddin, K. Kamaruddin and A. F. Hamzah, The Effect of bottom ash on fresh characteristic, compressive strength and water absorption of selfcompacting concrete, Appl. Mech. Mater., 660, 145-151, (2014).

[38]D. Chopra, R. Siddique and Kunal, Strength, permeability and microstructure of self-compacting concrete containing rice husk ash, Biosyst. Eng., 130, 72-80, (2015).

[39] H. Zhao, W. Sun, X. Wu and B. Gao, The properties of the self-compacting concrete with fly ash and ground granulated blast furnace slag mineral admixtures, J. Clean. Prod., 95, 66-74, (2015).

[40] S. Yang, X. Yue, X. Liu and Y. Tong, Properties of self-compacting lightweight concrete containing recycled plastic particles, Constr. Build. Mater., 84, 444-453, (2015). 
[41]H. Thanh, M. Müller, K. Siewert, and H. Ludwig, The mix design for self-compacting high performance concrete containing various mineral admixtures, J. Mater., 72, 51-62, (2015).

[42]M. Tennich, A. Kallel and M. Ben Ouezdou, Incorporation of fillers from marble and tile wastes in the composition of self-compacting concretes, Constr. Build. Mater., 91, 65-70, (2015).

[43]B. Safi, M. Saidi, A. Daoui, A. Bellal, A. Mechekak and K. Toumi, The use of seashells as a fine aggregate (by sand substitution) in self-compacting mortar (SCM), Constr. Build. Mater., 78, 430-438, (2015).

[44]C. Shi, Z. Wu, K. Lv and L. Wu, A review on mixture design methods for self-compacting concrete, Constr. Build. Mater., 84, 387-398, (2015).

[45]ERMCO, The European Guidelines for Self-Compacting Concrete, Eur. Guidel. Self Compact. Concr., (2005). 